\title{
Analisis Penerapan Sistem Pendukung Keputusan Terhadap Seleksi Penerima Beasiswa BBM (Bantuan Belajar Mahasiswa) Pada Perguruan Tinggi Menggunakan Metode Simple Additive Weighting (SAW) (Studi Kasus : AMIK Tunas Bangsa Pematangsiantar)
}

\author{
Anjar Wanto ${ }^{1}$, Hamonangan Damanik ${ }^{2}$ \\ ${ }^{1}$ Fakultas Ilmu Komputer-Teknologi Informasi Universitas Sumatera Utara \\ ${ }^{2}$ AMIK Tunas Bangsa Pematangsiantar \\ anjarwanto@gmail.com
}

\begin{abstract}
Abstrak - AMIK Tunas Bangsa merupakan Perguruan Tinggi di Pematangsiantar yang secara rutin menyalurkan bantuan dana beasiswa dari pemerintah kepada mahasiswa yang kurang mampu. Banyaknya pendaftar peserta beasiswa membuat kesulitan dalam menangani pengolahan data, sehingga diperlukan perangkat lunak untuk mempermudah pengolahan data tersebut. Penentuan kriteria penerima beasiswa ditentukan dari penghasilan orangtua, usia, semester, jumlah tanggungan orangtua, dan nilai Indeks Prestasi Komulatif (IPK) mahasiswa. Setelah itu, digunakan metode SAW (Simple Additive Weighting) pada sebuah sistem pendukung keputusan. Kemudian untuk merancang sebuah sistem pendukung keputusan diperlukan beberapa tahap yaitu dengan mengetahui Diagram Use Case, dan menerapkannya ke dalam suatu software/program yang akan dibangun menggunakan bahasa pemrograman visual berbasis desktop. Sistem pendukung keputusan calon penerima beasiswa pada AMIK Tunas Bangsa Pematangsiantar dengan Metode Simple Additive Weighting (SAW) ini dapat menghasilkan alternatif terbaik, sehingga seleksi penerimaan calon mahasiswa penerima beasiswa dapat berjalan secara tepat dan sesuai dengan yang diharapkan.
\end{abstract}

Kata kunci : SPK, Beasiswa, SAW

\section{PENDAHULUAN}

\section{A. Latar Belakang}

Disetiap lembaga pendidikan khususnya pada Perguruan Tinggi banyak sekali beasiswa yang ditawarkan kepada mahasiswa. Ada beasiswa yang berasal dari pemerintah maupun dari pihak swasta. Untuk mendapatkan beasiswa tersebut maka harus sesuai dengan aturan yang telah ditetapkan. Kriteria yang ditetapkan antara lain indeks prestasi akademik, pengasilan orang tua, jumlah saudara kandung, jumlah tanggungan orang tua, semester dan lain-lain. Tidak semua mahasiswa yang mengajukan permohonan untuk menerima beasiswa dapat dikabulkan, karena jumlah mahasiswa yang mengajukan permohonan sangat banyak, oleh karena perlu dibangun suatu sistem pendukung keputusan yang dapat membantu memberikan rekomendasi penerima beasiswa.

\section{B. Tinjauan Pustaka}

Menurut Alter (Kusrini, 2007 : 15) 'Sistem Pendukung Keputusan merupakan sistem informasi interaktif yang menyediakan informasi, pemodelan, dan pemanipulasian data. Sistem itu digunakan untuk membantu pengambilan keputusan dalam situasi yang semistruktur dan situasi yang terstruktur, dimana tidak seorang pun tahu secara pasti bagaimana keputusan seharusnya dibuat'. Sistem Pendukung Keputusan biasanya dibangun untuk mendukung solusi atas suatu masalah atau untuk mengevaluasi suatu peluang. Sistem Pendukung Keputusan yang seperti itu disebut dengan Aplikasi DSS. Aplikasi DSS digunakan dalam pengambilan keputusan. Aplikasi DSS menggunakan CBIS (Computer Based Information Systems) yang fleksibel, interaktif, dan dapat diadaptasi, yang dikembangkan untuk mendukung solusi atas masalah menajemen spesifik yang tidak terstruktur. Aplikasi DSS menggunakan data, memberikan antarmuka pengguna yang mudah, dan dapat menggabungkan pemikiran pengambil keputusan.

Ditinjau dari tingkat teknologi, DSS dibagi menjadi 3, yaitu:

1. SPK Sepesifik

SPK spesifik bertujuan membantu memecahkan suatu masalah dengan karakteristik tertentu. Misalnya, SPK penentuan harga suatu barang.

2. Pembangkit SPK

Suatu software yang khusus digunakan untuk membangun dan mengembangkan SPK. Pembangkit SPK akan memudahkan perancang dalam membangun SPK spesifik.

3. Perlengkapan SPK

Berupa software dan hardwareyang digunakan atau mendukung pembangunan SPK spesifik maupun pembangkit SPK.

Berdasarkan tingkat dukungannya, DSS dibagi menjadi 6, yaitu: 


\section{Retrieve Information Elements}

Inilah dukungan terendah yang bisa diberikan oleh DSS, yakni berupa akses selektif terhadap informasi. Misakkan manajer bermaksud mencari tahu informasi mengenai data penjualan atas suatu area pemasaran tertentu.

2. Analyze Entire File

Dalam tahapan ini, para manajer diberi akses untuk melihat dan menganalisis file secara lengkap. Misalnya, manajer bisa membuat laporan khusus penilaian persediaan dengan melihat file persediaan atau manajer bisa memperoleh laporan gaji bulanan dari file penggajian.

3. Prepare Report from Multiple Files

Dukungan seperti ini cenderung dibutuhkan mengingat para manajer berhubungan dengan banyak aktivitas dalam satu momen tertentu.

4. Estimate Decition Consequences

Dalam tahapan ini, manajr dimungkinkan untuk melihat dampak dari setiap keputusan yang mungkin diambil. Misalnya, manajer dimungkinkan memasukkan unsur harga dalam sebuah model untuk melihat pengaruhanya terhadap laba usaha.

5. Propose Decision

Dukungan di tahapan ini sedikit lebih maju lagi. Suatu alternatif keputusan bisa disodorkan ke tahapan manajer untuk dipertimbangkan.

6. Make Decision

Ini adalah jenis dukungan yang sangat diharapkan dari DSS. Tahapan ini akan memberikan sebuah keputusan yang tinggal menunggu legitimasi dari manajer untuk dijalankan.

\section{Tujuan Riset}

Tujuan dilakukannya riset ini adalah sebagai berikut:

1. Untuk menerapkan metode Simple Additive Weight $(S A W)$ yang digunakan sebagai proses seleksi calon pergawai dengan tepat dan akurat untuk mengetahui kelayakan mahasiswa untuk menerima bantuan beasiswa.

2. Untuk membuat sistem pendukung keputusan penyeleksian calon mahasiswa yang menerima beasiswa dengan metode SAW (Simple Additive Weighting)pada AMIK Tunas Bangsa Pematangsiantar.

3. Menjelaskan faktor-faktor atau kriteria yang memperngaruhi proses seleksi calon mahasiswa yang menerima bantuan beasiswa pada AMIK Tunas Bangsa Pematangsiantar.

\section{Sistematika Pembahasan}

Sistematika pembahasan dalam penelitian ini terbagi kedalam tiga bagian yang disusun secara sistematis agar mempermudah pembaca dalam memahami isi riset ini, yaitu sebagai berikut:
Pendahuluan ini berisi tentang Latar Belakang kenapa riset dilakukan, tinjauan pustaka yang berkaitan dengan riset, tujuan terperinci dari riset ini serta Sistematika Pembahasan.

\section{II : ANALISA DAN PERANCANGAN}

Pada tahap ini dilakukan analisa permasalahan dan kebutuhan sistem yang akan dibuat. Pada tahap ini juga akan dilakukan suatu perancangan aplikasi sistem pendukung keputusan untuk menyeleksi calon mahasiswa yang menerima beasiswa denga metode Simple Additive Weighting (SAW)

\section{III : HASIL DAN PEMBAHASAN}

Bagian ini berisi tentang bagaimana alur kerja sistem terhadap program Sistem Pendukung Keputusan yang dibuat serta melakukan pembahasan hasil keseluruhan yang dapat dilakukan program.

\section{IV : KESIMPULAN}

Pembahasan pada bagian ini berisi kesimpulan yang merupakan pendapat terakhir berdasarkan uraianuraian yang telah dijelaskan pada topik pendahuluan serta dari topik hasil dan pembahasan.

\section{ANALISA DAN PERANCANGAN}

\section{A. Langkah-Langkah Pemodelan DSS}

Saat melakukan pemodelan dalam pembangunan DSS dilakukan langkah-langkah sebagai berikut:

1. Studi Kelayakan (Intelligence)

Pada langkah ini, sasaran ditentukan dan dilakukan pencarian prosedur, pengumpulan data, identifikasi masalah, identifikasi kepemilikan masalah, klasifikasi masalah, hingga akhirnya terbentuk sebuah pernyataan masalah.

2. Perancangan (Design)

Pada tahapan ini akan diformulasikan model yang akan digunakan dan kriteria-kriteria yang ditentukan. Setelah itu, dicari alternatif model yang bisa menyelesaikan permasalahan tersebut.

3. Pemilihan (Choice)

Setelah pada tahap design ditentukan berbagai alternatif model beserta variabel-variabelnya, pada tahapan ini akan dilakukan pemilihan modelnya, termasuk solusi dari model tersebut. Selanjutnya, dilakukan analisis sensitivitas, yakni dengan mengganti beberapa variabel.

4. Membuat DSS

Setelah menentukan modelnya, berikut adalah mengimplementasikannya dalam aplikasi DSS. 


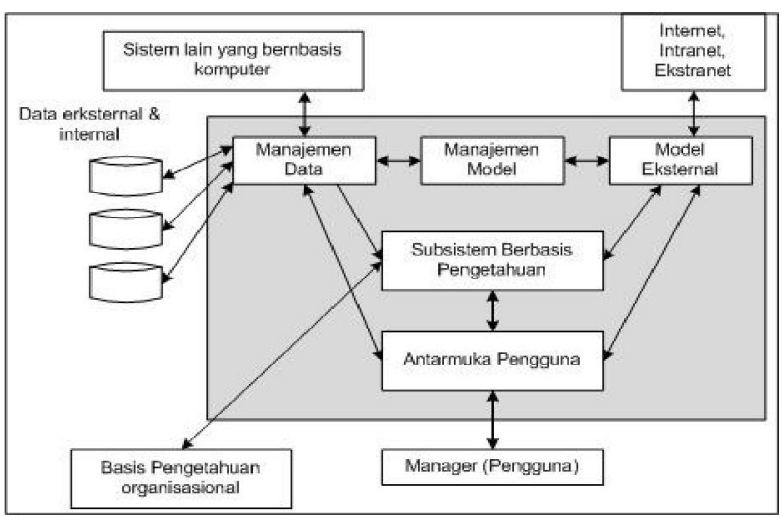

Gambar 1. Arsitektur DSS (Decisions Support System)

\section{B. Metode Simple Additive Weighting (SAW)}

Fuzzy Multiple Attribute Decision Making (FMADM) adalah suatu metodeyang digunakan untuk mencari alternative optimal dari sejumlah alternatif dengankriteria tertentu. Inti dari Multiple Attribute Decision Making (FMADM)adalah menentukan nilai bobot untuksetiap atribut, kemudian dilanjutkandengan proses perankingan yang akan menyeleksi alternatif yang sudah diberikan.

Metode $S A W$ adalah salah satumetode dari Multiple Attribute Decision Making (FMADM) yang paling seringdigunakan. Metode ini merupakan dasardari sebagian metode FMADM yangseperti $S A W$ dan PROMETHEE yangmenghitung nilai akhir alternatif yang diberikan.Metode $S A W$ sering juga dikenalistilah metode penjumlahan terbobot.Konsep dasar metode $S A W$ adalahmencari penjumlahan terbobot darirating kinerja pada setiap alternatif pada semua atribut.

Konsep dasar metode Simple Additive Weighting $(S A W)$ adalah mencari penjumlahan terbobot dari rating kinerja pada setiap alternatif pada semua atribut. Metode Simple Additive Weighting (SAW) membutuhkan proses normalisasi matriks keputusan (X) ke suatu skala yang dapat diperbandingkan dengan semua rating alternatif yang ada. Metode ini merupakan metode yang paling terkenal dan paling banyak digunakan dalam menghadapi situasi Multiple Attribute Decision Making (MADM). MADM itu sendiri merupakan suatu metode yang digunakan untuk mencari alternatif optimal dari sejumlah alternatif dengan kriteria tertentu.

Metode Simple Additive Weighting (SAW) ini mengharuskan pembuat keputusan menentukan bobot bagi setiap atribut. Skor total untuk alternatif diperoleh dengan menjumlahkan seluruh hasil perkalian antara rating (yang dapat dibandingkan lintas atribut) dan bobot tiap atribut. Rating tiap atribut haruslah bebas dimensi dalam arti telah melewati proses normalisasi matriks sebelumnya.

Langkah Penyelesaian Simple Additive Weighting $(S A W)$ sebagai berikut :

1. Menentukan kriteria-kriteria yang akan dijadikan acuan dalam pengambilan keputusan, yaitu $\mathrm{Ci}$.
2. Menentukan rating kecocokan setiap alternatif pada setiap kriteria.

3. Membuat matriks keputusan berdasarkan kriteria(Ci), kemudian melakukan normalisasi matriks berdasarkan persamaan yang disesuaikan dengan jenis atribut (atribut keuntungan ataupun atribut biaya) sehingga diperoleh matriks ternormalisasi R.

4. Hasil akhir diperoleh dari proses perankingan yaitu penjumlahan dari perkalian matriks ternormalisasi $\mathrm{R}$ dengan vektor bobot sehingga diperoleh nilai terbesar yang dipilih sebagai alternatif terbaik (Ai)sebagai solusi.

Formula untuk melakukan normalisasi tersebut adalah : $r i j=\left\{\begin{array}{c}\frac{x i j}{m a x^{x i j}} \text { jika } j \text { adalah attribut keuntungan (benefit) } \\ \frac{\text { min }^{x i j}}{x i j} \text { jika } j \text { adalah attribut biaya }(\text { cost })\end{array}\right.$

Dimana :

rij $\quad=$ rating kinerja ternormalisasi

Maxij = nilai maksimum dari setiap baris dan kolom

Minij = nilai minimum dari setiap baris dan kolom

Xij = baris dan kolom dari matriks

Dengan rij adalah rating kinerja ternormalisasi dari alternatif Ai pada atribut $\mathrm{Cj} ; \mathrm{i}=1,2, \ldots \mathrm{m}$ dan $\mathrm{j}=$ $1,2, \ldots, \mathrm{n}$.

Nilai preferensi untuk setiap alternatif (Vi) diberikan sebagai :

$$
v i=\sum_{j=1}^{n i} w i r i j
$$

Dimana :

$$
\begin{aligned}
& \mathrm{Vi}=\text { Nilai akhir dari alternative } \\
& \text { wj } \quad=\text { Bobot yang telah ditentukan } \\
& \text { rij } \quad=\text { Normalisasi matriks }
\end{aligned}
$$

Nilai Vi yang lebih besar mengindikasikan bahwa alternative Ai lebih terpilih (aeroyid, 2014).

Tabel 1. Perhitungan sederhana Simple Additive

\begin{tabular}{|l|l|l|l|l|}
\multicolumn{4}{c|}{ Weighting } \\
\cline { 2 - 5 } Alternatif & \multicolumn{4}{|c|}{ Kriteria } \\
\cline { 2 - 5 } & $C 1$ & C2 & $C 3$ & $C 4$ \\
\hline Anjar & 70 & 50 & 80 & 60 \\
\hline Wanto & 50 & 60 & 82 & 70 \\
\hline Anang & 85 & 55 & 80 & 75 \\
\hline Putri & 82 & 70 & 65 & 85 \\
\hline Dani & 75 & 75 & 85 & 74 \\
\hline Sugeng & 62 & 50 & 75 & 80 \\
\hline
\end{tabular}

- Proses normalisasi:

$$
\begin{aligned}
& r_{11}=\frac{70}{\max \{70 ; 50 ; 85 ; 82 ; 75 ; 62\}}=\frac{70}{85}=0,82 \\
& r_{21}=\frac{70}{\max \{70 ; 50 ; 85 ; 82 ; 75 ; 62\}}=\frac{50}{85}=0,59 \\
& r_{12}=\frac{50}{\max \{50 ; 60 ; 55 ; 70 ; 75 ; 50\}}=\frac{50}{75}=0,67 \\
& r_{22}=\frac{60}{\max \{50 ; 60 ; 55 ; 70 ; 75 ; 50\}}=\frac{60}{75}=0,80
\end{aligned}
$$


Dan seterusnya ...

Selanjutnya hasil normalisasi dibentuk kedalam matrix

$$
\mathrm{R}=\left[\begin{array}{cccc}
0,82 & 0,67 & 0,94 & 0,71 \\
0,59 & 0,80 & 0,96 & 0,82 \\
1 & 0,73 & 0,94 & 0,88 \\
0,96 & 0,93 & 0,76 & 1 \\
0,88 & 1 & 1 & 0,87 \\
0,73 & 0,67 & 0,88 & 0,94
\end{array}\right]
$$

- Proses perankingan dengan menggunakan bobot yang telah diberikan oleh pengambil keputusan:

$$
\begin{aligned}
& \mathrm{W}=\left[\begin{array}{llll}
0,35 & 0,25 & 0,25 & 0,15
\end{array}\right] \\
& \mathrm{V}_{1}=(0,35)(0,82)+(0,25)(0,67)+(0,25)(0,94)+ \\
& (0,15)(0,71)=0,796 \\
& \mathrm{~V}_{2}=(0,35)(0,59)+(0,25)(0,80)+(0,25)(0,96)+ \\
& (0,15)(0,82)=0,770 \\
& \mathrm{~V}_{3}=(0,35)(1,00)+(0,25)(0,73)+(0,25)(0,94)+ \\
& (0,15)(0,88)=0,900 \\
& \mathrm{~V}_{4}=(0,35)(0,96)+(0,25)(0,93)+(0,25)(0,76)+ \\
& (0,15)(1,00)=0,909 \\
& \mathrm{~V}_{5}=(0,35)(0,88)+(0,25)(1,00)+(0,25)(1,00)+ \\
& (0,15)(0,87)=0,939 \\
& \mathrm{~V}_{6}=(0,35)(0,73)+(0,25)(0,67)+(0,25)(0,88)+ \\
& (0,15)(0,94)=0,784
\end{aligned}
$$

- Nilai terbesar ada pada $V_{5}$ sehingga alternatif $A_{5}$ adalah alternatif yang terpilih sebagai alternatif terbaik.

- Dengan kata lain, Dani akan terpilih sebagai kepala unit sistem informasi.

\section{Analisa Permasalahan}

Dalam seleksi calon penerima yang baik memerlukan alat bantu yang tepat, yang menggunakan komputer sebagai suatu sarana yang dapat membantu sumber daya manusia untuk mendapatkan banyak informasi secara tepat dan akurat dengan suatu metode dan perhitungan sistematis yaitu metode SAW, metode ini dapat memberikan alternatif pilihan. Pada dasarnya metode SAW merupakan suatu metode untuk memecahkan suatu permasalahan yang kompleks dan tidak tersetruktur ke dalam kelompoknya, mengatur kelompok tersebut ke dalam suatu hierarki.

Layaknya sebuah metode analisis, SAW pun memiliki kelebihan dalam sistem analisisnya yaitu SAW memecahkan permasalahan yang kompleks melalui pendekatan sistem dan pengintegrasian secara deduktif dan saling ketergantungan (inter dependence) yakni menggunakan elemen-elemen yang saling bebas dan tidak memiliki hubungan linear. Dalam perhitungan pada seleksi calon penerima bantuan dana beasiswa dengan SAW ini akan dibuat suatu perhitungan matriks-matriks berdasarkan kriterakriteria yang ada.
Pada bagian pembahasan ini dijelaskan secara umum bagaimana cara menghitung dengan menggunakan metode SAW, Ada beberapa langkah untuk mengerjakan pemecahan pengambilan keputusan dari suatu set alternatif dengan beberapa kriteria menggunakan metode SAW.

Adapun langkah-langkah perhitungan dengan menggunakan metode AHP adalah sebagai berikut :

1. Menentukan nilai kriteria $\mathrm{Cj}$ pada suatu set alternatif Ai. Beserta bobot preferensi (Wj) setiap kriteria $\mathrm{Cj}$, berikut kriteria-kriteria yang dibutuhkan dalam pengambilan keputusan menentukan calon penerima beasiswa :

Tabel 2. Kriteria

\begin{tabular}{|c|l|c|}
\hline Kriteria & \multicolumn{1}{|c|}{ Keterangan } & Bobot \\
\hline K1 & Jumlah Pendapatan Orang tua & $30 \%$ \\
\hline K2 & Jumlah Tanggungan Orang tua & $20 \%$ \\
\hline K3 & Status Orang tua & $10 \%$ \\
\hline K4 & Semester & $10 \%$ \\
\hline K5 & IPK & $30 \%$ \\
\hline \multicolumn{2}{|c}{ Sumber : AMIK Tunas Bangsa Pematangsiantar }
\end{tabular}

Tabel 3. Jumlah Pendapatan Orang Tua

\begin{tabular}{|c|l|c|}
\hline No & Nama Mahasiswa & Pendapatan Ortu \\
\hline 1. & Chairunnisa Tanjung & 1.500 .000 \\
\hline 2. & Pratiwi & 2.000 .000 \\
\hline 3. & Devi Andini Damanik & 3.000 .000 \\
\hline 4. & Nurul Syakirah & 2.200 .000 \\
\hline 5. & Andi Suseno & 2.000 .000 \\
\hline
\end{tabular}

Tabel 4. Jumlah Tanggungan Orang Tua

\begin{tabular}{|c|l|c|}
\hline No & \multicolumn{1}{|c|}{ Nama Mahasiswa } & $\begin{array}{c}\text { Jumlah } \\
\text { Tanggungan }\end{array}$ \\
\hline 1. & Chairunnisa Tanjung & 3 \\
\hline 2. & Pratiwi & 7 \\
\hline 3. & Devi Andini Damanik & 1 \\
\hline 4. & Nurul Syakirah & 4 \\
\hline 5. & Andi Suseno & 5 \\
\hline
\end{tabular}

Tabel 5. Status Orang Tua

\begin{tabular}{|c|l|c|}
\hline No & \multicolumn{1}{|c|}{ Nama Mahasiswa } & $\begin{array}{c}\text { Status Orang } \\
\text { Tua/ Wali }\end{array}$ \\
\hline 1. & Chairunnisa Tanjung & Janda \\
\hline 2. & Pratiwi & Lengkap \\
\hline 3. & Devi Andini Damanik & Lengkap \\
\hline 4. & Nurul Syakirah & Lengkap \\
\hline 5. & Andi Suseno & Lengkap \\
\hline
\end{tabular}

Tabel 6. Semester

\begin{tabular}{|c|l|c|}
\hline No & \multicolumn{1}{|c|}{ Nama Mahasiswa } & Semester \\
\hline 1. & Chairunnisa Tanjung & 5 \\
\hline 2. & Pratiwi & 5 \\
\hline 3. & Devi Andini Damanik & 5 \\
\hline 4. & Nurul Syakirah & 5 \\
\hline 5. & Andi Suseno & 3 \\
\hline
\end{tabular}

Tabel 7. IPK

\section{Algoritma Sistem}




\begin{tabular}{|c|l|c|}
\hline No & \multicolumn{1}{|c|}{ Nama Mahasiswa } & IPK \\
\hline 1. & Chairunnisa Tanjung & 3.40 \\
\hline 2. & Pratiwi & 3.10 \\
\hline 3. & Devi Andini Damanik & 2.80 \\
\hline 4. & Nurul Syakirah & 3.50 \\
\hline 5. & Andi Suseno & 3.09 \\
\hline
\end{tabular}

Tabel 8. Konversi nilai dari masing-masing kriteria kedalam angka fuzy

\begin{tabular}{|c|l|c|c|c|c|c|}
\hline NIM & \multicolumn{1}{|c|}{ Nama } & $\begin{array}{c}\text { Pendapatan } \\
\text { Orang Tua }\end{array}$ & $\begin{array}{c}\text { Jumlah } \\
\text { Tanggungan } \\
\text { Orang Tua }\end{array}$ & $\begin{array}{c}\text { Status } \\
\text { Orang Tua }\end{array}$ & Sem & IPK \\
\hline 20130030215 & $\begin{array}{l}\text { Chairunnisa } \\
\text { Tanjung }\end{array}$ & 1 & 0.5 & 1 & 1 & 0.75 \\
\hline 20130030118 & Pratiwi & 0.75 & 1 & 0.25 & 1 & 0.75 \\
\hline 20130030089 & $\begin{array}{l}\text { Devi Andini } \\
\text { Damanik }\end{array}$ & 0.25 & 0.25 & 1 & 1 & 0.50 \\
\hline 20130030256 & Nurul Syakirah & 0.75 & 0.5 & 0.25 & 1 & 1 \\
\hline 20140030334 & Andi S & 0.75 & 0.75 & 0.25 & 0.5 & 0.75 \\
\hline
\end{tabular}

Dari data tabel diatas kemudian kita ubah kedalam bentuk matriks keputusan persamaan (1) seperti dibawah ini :

Matriks X $\left(\begin{array}{ccccc}1 & 0.5 & 1 & 1 & 0.75 \\ 0.75 & 1 & 0.25 & 1 & 0.75 \\ 0.25 & 0.25 & 1 & 1 & 0.50 \\ 0.75 & 0.5 & 0.25 & 1 & 1 \\ 0.75 & 0.75 & 0.25 & 0.5 & 0.75\end{array}\right)$

2. Menghitung Rij dengan formula normalisasi sehingga mendapat matrik ternormalisasi.

$r i j=\left\{\begin{array}{l}\frac{x i j}{\max ^{x i j}} \text { jika } j \text { adalah attribut keuntungan (benefit) } \\ \frac{m^{x i n}}{x i j} \text { jika } j \text { adalah attribut biaya (cost) }\end{array}\right.$

\section{Keterangan :}

rij = rating kinerja ternormalisasi.

$\operatorname{Max}_{\mathrm{ij}}=$ nilai maksimum dari setiap baris dan kolom.

$\operatorname{Min}_{\mathrm{ij}}=$ nilai minimum dari setiap baris dan kolom

$\mathrm{X}_{\mathrm{ij}} \quad=$ nilai attribut yang dimiliki dari setiap

kriteria

Benefit $=$ jika nilai terbesar adalah terbaik.

Cost $=$ jika nilai terkecil adalah terbaik.

- Untuk Nilai Pendapatan Orang Tua, Jadi :

Chairunnisa Tanjung $=\frac{1}{\operatorname{Max}\{1: 0.75: 0.250 .75: 0.75\}}=$ $\frac{1}{1}=1$

Pratiwi

$\frac{0.75}{1}=1$

$$
=\frac{0.75}{\operatorname{Max}\{1: 0.75: 0.250 .75: 0.75\}}=
$$

Devi Andini Damanik $=\frac{0.25}{\operatorname{Max}\{1: 0.75: 0.250 .75: 0.75\}}=$ $\frac{0.25}{1}=0.25$

Nurul Syakirah

$$
=\frac{0.75}{\operatorname{Max}\{1: 0.75: 0.250 .75: 0.75\}}=
$$

$\frac{0.75}{1}=0.75$

Andi Suseno

$\frac{0.75}{1}=0.75$
- Untuk Nilai Jumlah Tanggungan Orang Tua, Jadi :

Chairunnisa Tanjung $=\frac{0,5}{\operatorname{Max}\{0.5: 1: 0.2 \quad 50.5: 0.75\}}=$ $\frac{1}{1}=1$

Pratiwi

$$
=\frac{1}{\operatorname{Max}\{0.5: 1: 0.2 \quad 50.5: 0.75\}}=
$$

$\frac{1}{1}=1$

Devi Andini Damanik $=\frac{0.25}{\operatorname{Max}\{0.5: 1: 0.250 .5: 0.75\}}=$ $\frac{0.25}{1}=0.25$

Nurul Syakirah

$\frac{0.5}{1}=0.5$

Andi Suseno

$$
=\frac{0.5}{\operatorname{Max}\{0.5: 1: 0.2 \quad 50.5: 0.75\}}=
$$

$\frac{0.75}{1}=0.75$

- Untuk Status Orang Tua, Jadi :

Chairunnisa Tanjung $=\frac{1}{\operatorname{Max}\{1: 0.251: 0.250 .2 \$}=$ $\frac{1}{1}=1$

Pratiwi

$$
=\frac{0.75}{\operatorname{Max}\{0.5: 1: 0.250 .5: 0.75\}}=
$$

$\frac{0.25}{1}=0.25$

Devi Andini Damanik $=\frac{1}{\operatorname{Max}\{1: 0.251: 0.250 .2 \xi}=$ $\frac{1}{1}=1$

Nurul Syakirah

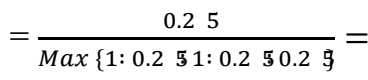

$\frac{0.25}{1}=0.25$

Andi Suseno

$\frac{0.25}{1}=0.25$

$=\frac{0.25}{\operatorname{Max}\{1: 0.251: 0.250 .2 \$}=$

Untuk Semester, Jadi :

Chairunnisa Tanjung $=\frac{1}{\operatorname{Max}\{1: 1: 1: 1: 0.5\}}=\frac{1}{1}=1$

Pratiwi $\quad=\frac{1}{\operatorname{Max}\{1: 1: 1: 1: 0.5\}}=\frac{1}{1}=1$

Devi Andini Damanik $=\frac{1}{\operatorname{Max}\{1: 1: 1: 1: 0.5\}}=\frac{1}{1}=1$

Nurul Syakirah

$=\frac{1}{\operatorname{Max}\{1: 1: 1: 1: 0.5\}}=\frac{1}{1}=1$

Andi Suseno

$=\frac{0.5}{\operatorname{Max}\{1: 1: 1: 1: 0.5\}}=\frac{0.5}{1}=$

0.5

- Untuk IPK, Jadi :

Chairunnisa Tanjung $=\frac{0.75}{\operatorname{Max}\{1: 1: 1: 1: 0.5\}}=\frac{0.75}{1}=$ 0.75

Pratiwi $\quad=\frac{0.75}{\operatorname{Max}\{1: 1: 1: 1: 0.5\}}=\frac{0.75}{1}=$

0.75

Devi Andini Damanik $=\frac{0.50}{\operatorname{Max}\{1: 1: 1: 1: 0.5\}}=\frac{0.50}{1}=$ 0.50

Nurul Syakirah

$$
=\frac{1}{\operatorname{Max}\{1: 1: 1: 1: 0.5\}}=\frac{1}{1}=1
$$

Andi Suseno

0.75 
Tabel 9. Diubah kedalam matriks keputusan R dengan

\begin{tabular}{|l|c|c|c|c|c|}
\hline \multicolumn{1}{|c|}{ Nama } & $\begin{array}{c}\text { Pendapatan } \\
\text { Orang Tua }\end{array}$ & $\begin{array}{c}\text { Jumlah } \\
\text { Tanggungan } \\
\text { Orang Tua }\end{array}$ & $\begin{array}{c}\text { Status } \\
\text { Orang } \\
\text { Tua }\end{array}$ & Sem & IPK \\
\hline $\begin{array}{l}\text { Chairunnisa } \\
\text { Tanjung }\end{array}$ & 1 & 0.5 & 1 & 1 & 0.75 \\
\hline Pratiwi & 0.75 & 1 & 0.25 & 1 & 0.75 \\
\hline $\begin{array}{l}\text { Devi Andini } \\
\text { Damanik }\end{array}$ & 0.25 & 0.25 & 1 & 1 & 0.50 \\
\hline $\begin{array}{l}\text { Nurul } \\
\text { Syakirah }\end{array}$ & 0.75 & 0.5 & 0.25 & 1 & 1 \\
\hline Andi Suseno & 0.75 & 0.75 & 0.25 & 0.5 & 0.75 \\
\hline
\end{tabular}

3. Melakukan proses perangkingan dengan menggunakan persamaan berikut :

$$
v i=\sum_{j=1}^{n i} w i r i j
$$

\section{Keterangan :}

$$
\begin{array}{ll}
\mathrm{Vi} & =\text { Nilai akhir dari alternatif } \\
\mathrm{wj} & =\text { Bobot yang telah ditentukan } \\
\text { rij } & =\text { Normalisasi matriks } \\
\text { Jadi } & :
\end{array}
$$

Chairunnisa Tanjung =

$$
\begin{aligned}
(0.30)(1)+(0.10)(0.5)+ & 0.10)(1)+(0.20)(1)+(0.30)(0.75) \\
& =0,3+0,05+0,1+0,2+0,225 \\
& =0,875
\end{aligned}
$$

Pratiwi

$(0.30)(0.75)+(0.10)(1)+(0.10)(0.25)+(0.20)(1)+(0.30)($

$$
\text { 0.75) }=0,225+0,1+0,025+0,2+0,225
$$$$
=0,775
$$

Devi Andini Damanik $=$

$(0.30)(0.25)+(0.10)(0.25)+(0.10)(1)+(0.20)(1)+(0.30)($

$$
0.50)=0,075+0,025+0,1+0,2+0,15
$$$$
=0,55
$$

Nurul Syakirah

$$
=
$$

$(0.30)(0.75)+(0.10)(0.5)+(0.10)(0.25)+(0.20)(1)+(0.30)$

$$
=0,225+0,05+0,025+0,2+0,3
$$

$$
=0,80
$$

Andi Suseno

$$
=
$$

$(0.30)(0.75)+(0.10)(0.75)+(0.10)(0.25)+(0.20)(5)+(0.3$ $0)(0.75)$

$$
=0,225+0,075+0,025+0,1+0,225
$$

$$
=0,65
$$

Hasil perangkingan diperoleh : V1 $=\mathbf{0 , 8 7 5}, \mathrm{V} 2=0,775$ $, \mathrm{V} 3==0,55, \mathrm{~V} 4=0,80, \mathrm{~V} 5=0,65$. Nilai terbesar ada pada V1, dengan demikian alternatif Chairunnisa Tanjung sebagai alternatif yang terpilih sebagai alternatif terbaik. Selengkapnya akan dijelaskan pada tabel berkut :

Tabel 10. Ranking

\begin{tabular}{|l|c|}
\hline \multicolumn{1}{|c|}{ Nama } & Nilai \\
\hline Chairunnisa Tanjung & 0.875 \\
\hline Pratiwi & 0,775 \\
\hline Devi Andini Damanik & 0,55 \\
\hline Nurul Syakirah & 0,80 \\
\hline Andi Suseno & 0.65 \\
\hline
\end{tabular}

\section{E. Diagram Dan Perancangan Sistem}

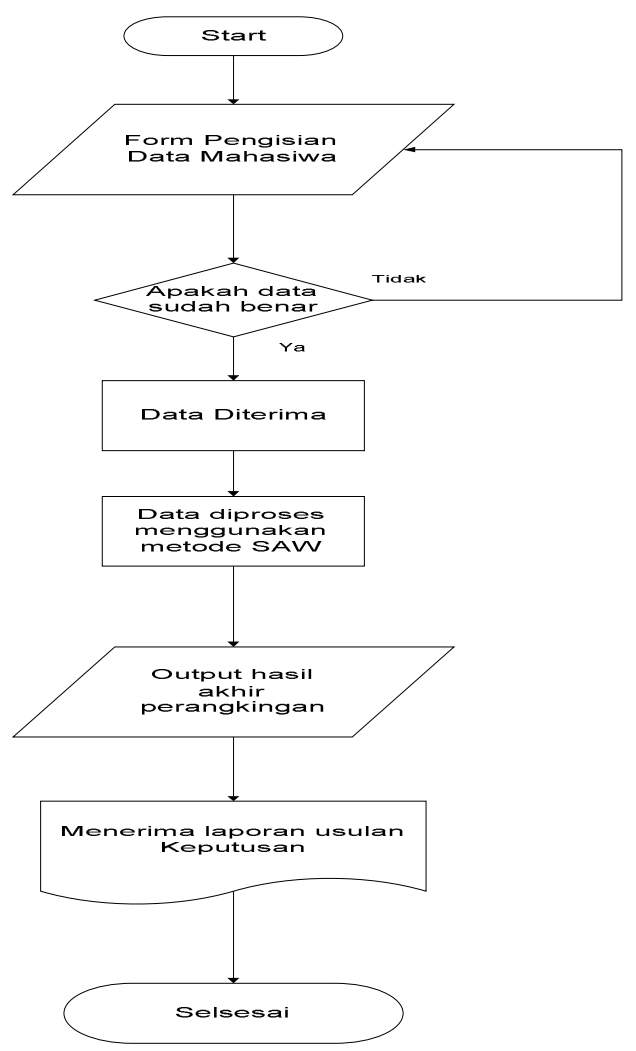

Gambar 2. Flowchart Sistem/Program

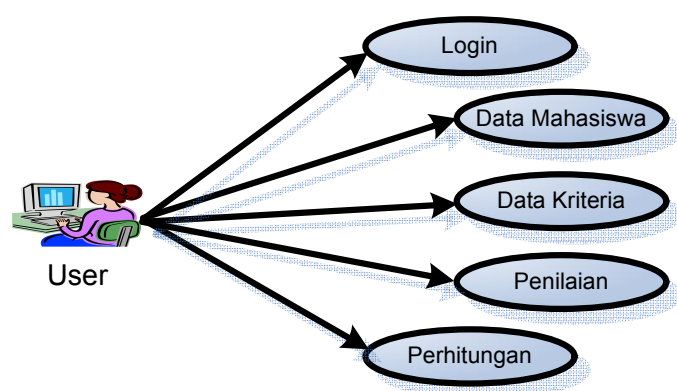

Gambar 3. Use Case Diagram 

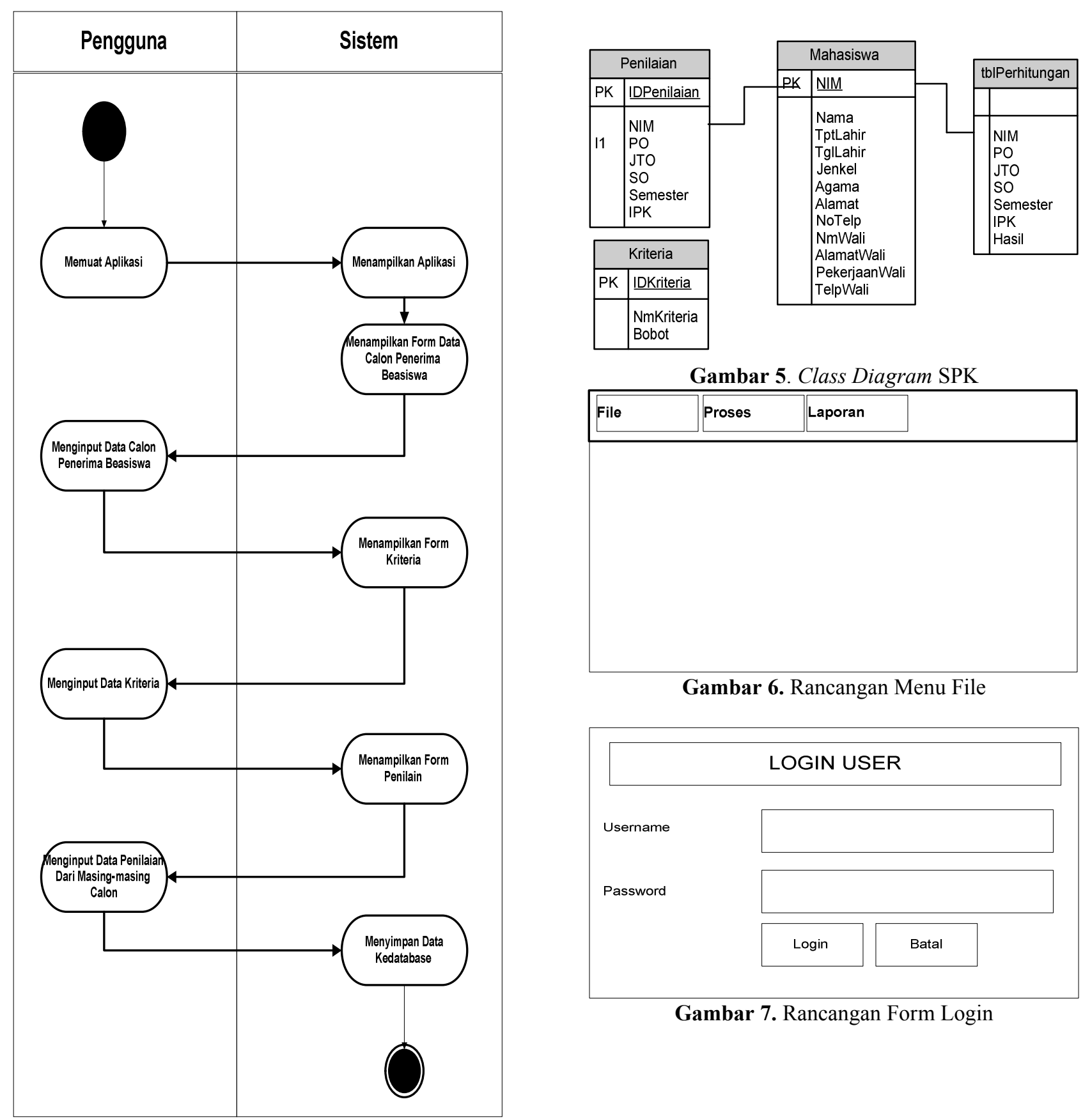

Gambar 5. Class Diagram SPK



Gambar 6. Rancangan Menu File

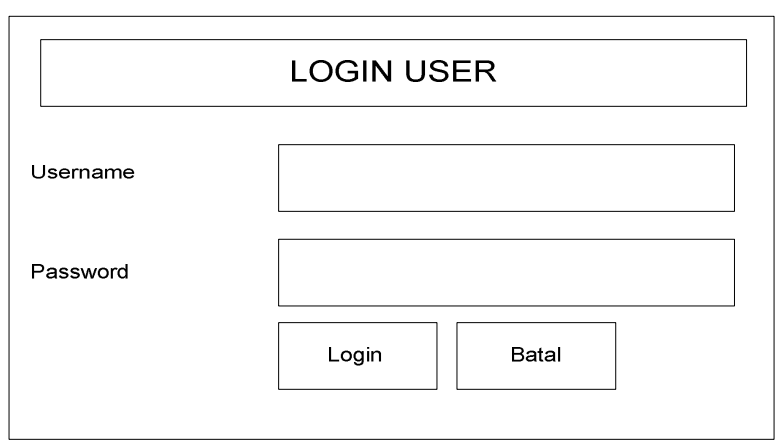

Gambar 7. Rancangan Form Login

Gambar 4. Activity Diagram Menentukan Penerima Beasiswa 


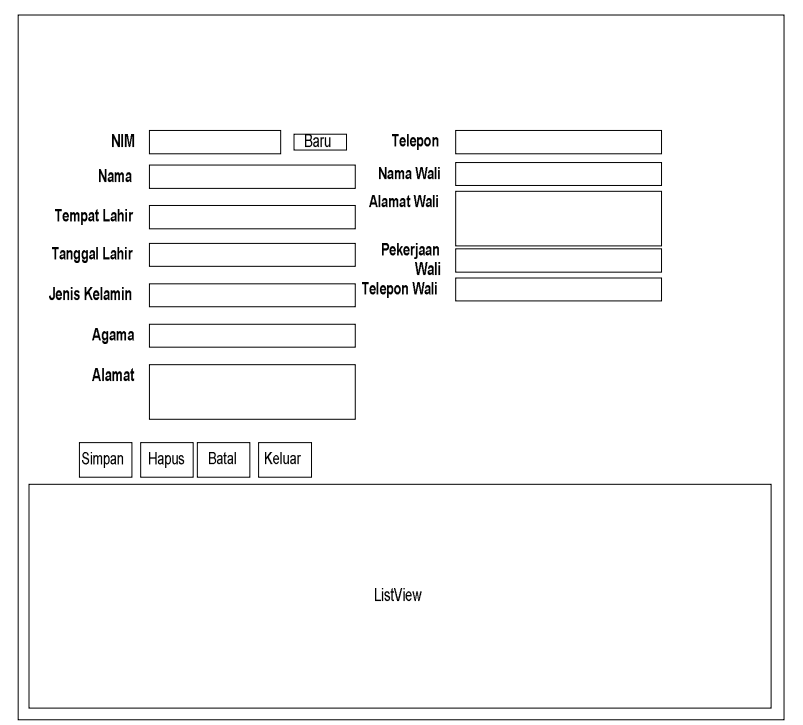

Gambar 8. Rancangan Form Mahasiswa

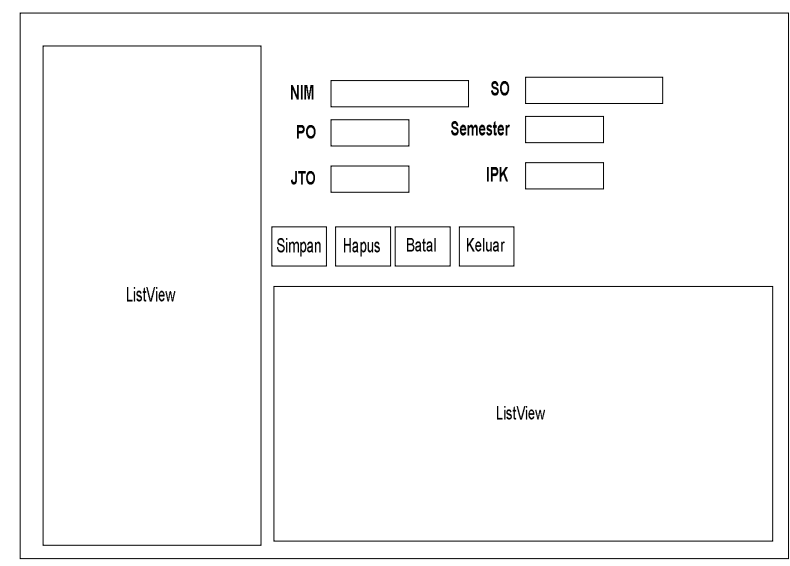

Gambar 9. Rancangan Form Penilaian

\section{DATA PERHITUNGAN}

Proses

Batal

Gambar 10. Rancangan Form Perhitungan

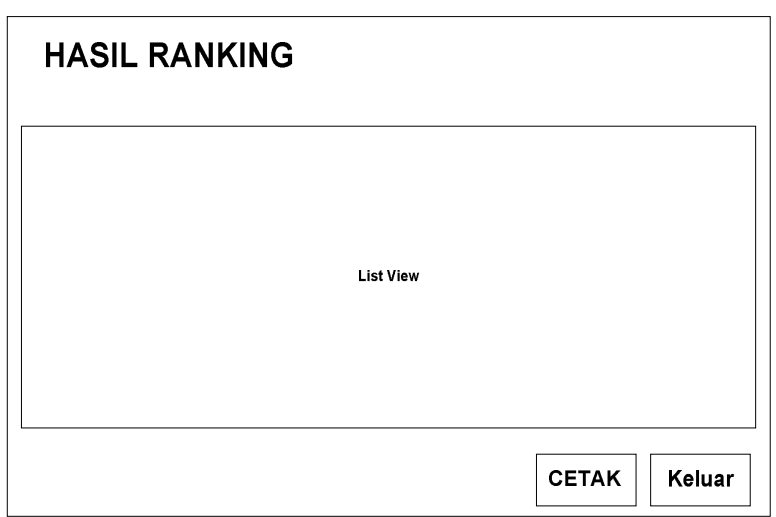

Gambar 11. Rancangan Form Hasil Rangking

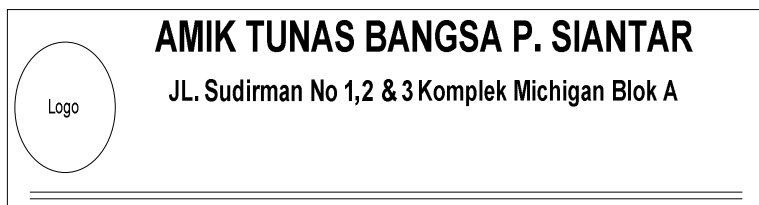

\section{DATA PENILAIAN}

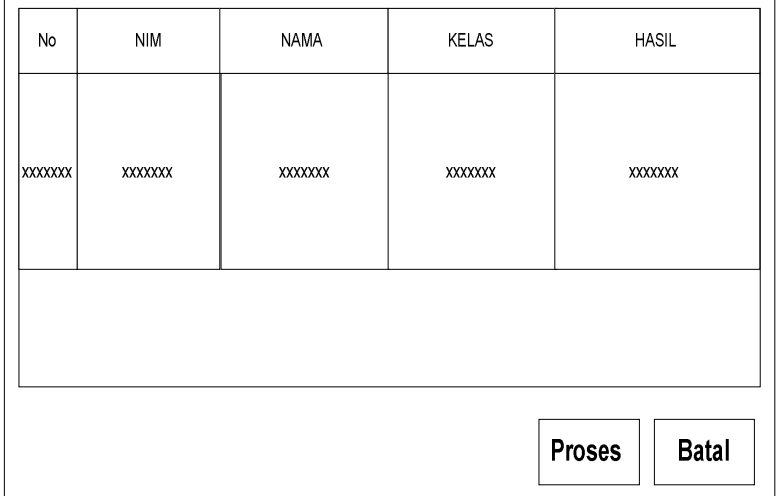

Gambar 12. Rancangan Form Laporan Penilaian

\section{HASIL DAN PEMBAHASAN}

Pada bagian ini akan dijelaskan mengenai hasil dari pembahasan-pembahasan topik diatas.

\section{A. Form Utama}

Form ini akan tampil pertama kali sewaktu menjalankan program sistem pendukung keputusan penilaian kinerja untuk menentukan calon penerima beasiswa dengan metode Simple Additive Weighting.

\section{Gambar 13. Form Utama}

\section{B. Form Login}


Pada form login, admin harus memasukkan usernam dan password. Jika username dan password dan kata sandi tidak sesuai maka proses login tidak dapat dilakukan, Menu login bermanfaat agar tidak sembarangan user bisa mengakses form- form yang ada di aplikasi sistem pendukung keputusan ini.

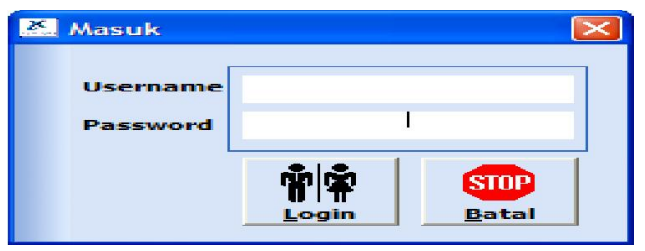

Gambar 14. Form Login

\section{Form Mahasiswa}

Pada Form mahasiswa user bisa melakukan pengolahan data mahasiswa berupa menambah, mengubah dan menghapus data mahasiswa yang terdapat pada database.



Gambar 15. Form Mahasiswa

\section{Form Penilaian}

Form ini digunakan untuk proses pemberian nilai dari masing-masing kriteria berdasarkan kemampuan yang dimiliki oleh masing-masing mahasiswa calon penerima beasiswa.



Gambar 16. Form Penilaian

\section{E. Form Perhitungan}

Pada form ini merupakan proses dimana perhitungan dilakukan dengan metode Simple Additive Weighting, hal pertama yang dilakukan setelah penentuan nilai dari masing-masing calon pada kriteria yang tersedia, selanjutnya ketika user mengklik button normalisasi maka nilai dari masing kriteria akan berubah menjadi angka fuzzy yang telah ditentukan.

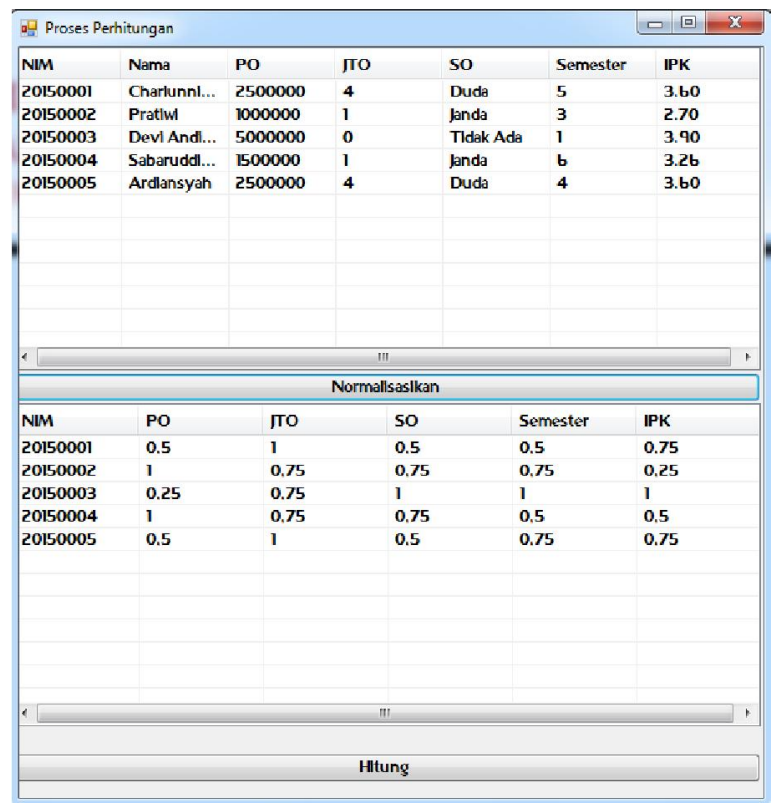

Gambar 17. Form Perhitungan

Selanjutnya ketika user mengklik button hitung makan akan tampil form hitung seperti gambar berikut ini :

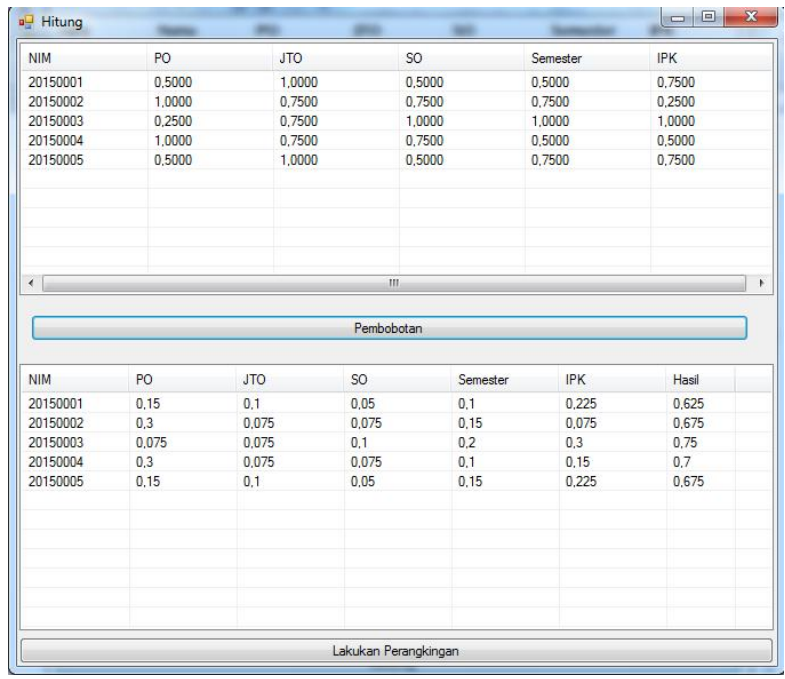

Gambar 18. Form Perhitungan Matriks

Jika user mengklik button pembobotan maka proses perhitungan dari baris dan kolom pada table matriks yang diatas yang dikalikan dengan bobot dari masingmasing kriteria dan hasilnya akan tampil pada table yang dibawah pada gambar diatas.

\section{F. Form Hasil Rangking}

Form Perangkingan meupakan form yang akan digunakan untuk proses menampilkan data hasil dari perhitungan yang dilakukan pada form perhitungan, data yang memiliki hasil yang paling tinggi yang akan ditampilkan paling atas artinya alternatif yang paling 
atas adalah alternatif yang paling layak mendapatkan bantuan dana beasiswa.



Gambar 19. Form Hasil Rangking

\section{G. Form Laporan Penilaian}

Pada laporan hasil ini terdapat data-data mahasiswa yang layak mendapatkan bantuan dana beasiswa pada AMIK Tunas Bangsa Pematangsiantar.

\begin{tabular}{|c|c|c|c|c|c|c|c|}
\hline & \multicolumn{7}{|c|}{$\begin{array}{l}\text { AMIK TUNAS BANGSA PEMATANGSIANTAR } \\
\text { Jalan Jendral Sudirman No } 1,2 \& 3 \text { Pematangsiantar }\end{array}$} \\
\hline & \multicolumn{7}{|c|}{ HASIL PENYELEKSIAN } \\
\hline NIIII & Nama & PO & JTO & so & Senester & PPK & Hasil \\
\hline 20150006 & JeviAndri & $001 / 3$ & 0,015 & 111 & 02 & 013 & $0 / 5$ \\
\hline $2015000 \mathrm{~K}$ &  & 03 & 0.075 & 0.075 & 01 & 0.15 & 07 \\
\hline 201500005 & $\begin{array}{l}\text { Demawanan } \\
\text { Nrciarsanac }\end{array}$ & 0.15 & & & & 0225 & \\
\hline 20150002 & & 03 & 0.075 & 0.075 & 015 & 0075 & 0.675 \\
\hline 20150001 & $\begin{array}{l}\text { Chariunisa } \\
\text { Taniung }\end{array}$ & 0.15 & 0.1 & 0.05 & 01 & 0.225 & 0.625 \\
\hline
\end{tabular}

Gambar 19. Form Hasil Penilaian

\section{KESIMPULAN DAN SARAN}

\section{A. Kesimpulan}

Dari perancangan aplikasi sistem pendukung keputusan untuk menentukan calon penerima beasiswa pada AMIK Tunas Bangsa Pematangsiantar yang telah diselesaikan ini, dapat diambil beberapa kesimpulan antara lain :

1. Proses seleksi beasiswa pada AMIK Tunas Bangsa Pematangsiantar meliputi beberapa kriteria yaitu pendapatan orangtua, jumlah tanggungan orangtua, status orangtua, semester dan IPK.

2. Penerapan metode Simple Additive Weighting dalam proses seleksi calon penerima beasiswa dengan tepat dan akurat adalah dengan membangun sebuah sistem yang dapat melakukan proses penilaian berdasarkan kriteria-kriteria yang telah ditentukan.

3. Aplikasi sistem pendukung keputusan penyeleksian calon penerima beasiswa pada AMIK Tunas Bangsa Pematangsiantar dirancang dengan membuat rancangan input, menggunakan bahasa pemrogaman berbasis visual, membuat database sebagai media penyimpan data yang diproses dan membuat output berupa laporan.

\section{B. Saran}

Adapun saran-saran yang diberikan sebagai pertimbangan kepada pihak-pihak yang berkepentingan untuk mengembangkan lebih lanjut lagi dan menyempurnakan hasil dari penelitian ini sehingga nantinya ini menjadi lebih baik lagi. Sarannya adalah sebagai berikut :

1. Pada dasarnya penerapan sistem ini masih sangat sederhana dan tentunya dengan penambahan beberapa fungsi pendukung lainnya, seperti tampilan-tampilan pada form, pemberian animasi dan yang lainnya, diharapkan dapat memaksimalkan fungsi dan efektivitas dari sistem.

2. Dalam penelitian ini juga belum dilengkapi dengan sebuah sistem keamanan. Dan diharapkan bagi user yang bersedia dan mampu dalam memperbaiki program sistem pendukung keputusan ini hendaknya dilakukan penambahan-penambahan fitur kemanan seperti anti virus dan sebagainya

\section{UCAPAN TERIMA KASIH}

Ucapan terima kasih sebesar-besarnya penulis ucapkan kepada :

1. Allah 'Azza Wa Jalla yang selalu memberikan Rahman dan Rahim nya sehingga penulis mampu menyelesaikan tulisan ini.

2. Baginda Rasulullah SAW, yang ajarannya selalu memberikan semangat dalam menjalani kehidupan ini.

3. Ayahanda, Ibunda beserta keluarga saya yang banyak membantu doa dan dukungan.

4. Adik seperjuangan saya Hamonangan Damanik, S.Kom. Yang telah sama-sama berjuang untuk menyelesaikan Riset ini.

5. H. M. A. Ridwansyah Putra beserta Dedy Hartama, ST, M.Kom selaku Ketua Yayasan dan Wakil Direktur 1 AMIK dan STIKOM Tunas Bangsa Pematangsiantar yang banyak memberikan bantuan moril dan motivasi.

6. DR. Rahmat Widia Sembiring, M.Sc.IT selaku Direktur AMIK dan STIKOM Tunas Bangsa Pematangsiantar.

7. Prof. DR. Muhammad Zarlis, M.Sc, Prof. DR. Opim Salim Sitompul, M.Si, Muhammad Andri Budiman, ST, M.Com.Sc, M.E.M, yang banyak memberikan motivasi dan dorongan agar penulis selalu rajin menulis dan meneliti.

8. Semua pihak yang tidak bisa saya sebutkan satu persatu.

\section{DAFTAR PUSTAKA}

\section{Artikel jurnal :}

[1] T. Limbong. Implementasi Metode Simple 
Additive Weighting (SAW) Untuk Pemilihan Pekerjaan Bidang Informatika. SNIKOM 2013 ICT System Security, 2013.

[2] K. Puspita dan P. H.Putra, Penerapan Metode Simple Additive Weighting (SAW) Dalam Menentukan Pendirian Lokasi Gramedia Di Sumatera Utara. Seminar Nasional Teknologi Informasi Dan Multimedia, ISSN : 2302-3805, 2015.

[3] Harsiti dan Roikotuljanah, Sistem Pendukung Keputusan Pemberian Kredit Mikro Utama Pada Pt.Bank Bjb Kcp Cikande Dengan Metode Simple Additive Weighting (SAW). Jurnal Sistem Informasi, Volume 1, Nomor 1, 29-32, 2014.

[4] S. D. Reskika, Perancangan Aplikasi Sistem Pendukung Keputusan Penentuan Lokasi Pemasaran Rumah Denagn Metode Simple Additive Weighting. Informasi dan Teknologi Ilmiah (INTI), Volume1, Nomor 12, Oktober 2013.

\section{Buku :}

[1] Leszek A. Maciaszek, Requirements Analysis and System Design, Third edition, ISBN 9780-321-44036-5, England, Addison-Wesley, 2007

[2] Al Fatta, Hanif. Analisis dan Perancangan Sistem Informasi Untuk Keunggulan Bersaing Perusahaaan dan Organissi Modern. Andi Offset. Yogyakarta. 2007.

[3] Kusrini. Konsep dan Aplikasi Sistem Pendukung Keputusan. Andi Offset. Yogyakarta. 2007

\section{Prosiding Seminar :}

[1] SNIKOM 2013, Implementasi Metode Simple Additive Weighting (SAW) Untuk Pemilihan Pekerjaan Bidang Informatika, ICT System Security, ISBN 979-458-684-6, 24 Agustus 2013.

[2] SNIKOM 2015, Sistem Pendukung Keputusan Dalam Penentuan Penerima Bantuan Pendidikan Dari Mderamen GBKP Kabanjahe, Industri Kreatif Berbasis Teknologi Informasi Dan Komunikasi, hal 288-292, ISBN 979-458831-8, 31 Oktober 2015.
[1] Aeroyid, Metode Simpel Additive Weighting $S A W .2014$. Website :

http://aeroyid.wordpress.com/2014/01/16/metode simple-additive-weighting-saw/.html, diakses tanggal 9 September 2015

[2] Wegi bae, Metode Simpel Additive Weighting $(S A W)$. 2013. Website :

http://belajarbersamawegi.blogspot.co.id/2013/06 /metode-simple-additive-weighting-saw.html, diakses tanggal 8 November 2015 .

[3] Wikipedia, Sistem Pendukung Keputusan, Perubahan Terakhir 4 Mei 2015. Website : https://id.wikipedia.org/wiki/Sistem pendukung keputusan diakses tanggal 8 November 2015.

\section{BIODATA PENULIS}

Anjar Wanto, memperoleh gelar Ahli Madya Komputer (A.Md) pada tahun 2010 di AMIK Tunas Bangsa Pematangsiantar, memperoleh gelar Sarjana Komputer (S.Kom), Jurusan Teknik Informatika Sekolah Tinggi Teknik Poliprofesi Medan, lulus tahun 2012.

Saat ini sedang menjalani studi pada Program Pasca Sarjana Magister Fakultas Ilmu Komputer Dan Teknologi Informasi Universitas Sumatera Utara (FASILKOM-TI USU).

Penulis juga saat ini menjadi Dosen Magang pada AMIK-STIKOM Tunas Bangsa Pematangsiantar.

Email : anjarwanto@gmail.com

\section{Internet :}

